\title{
THE ISSUES OF THE MANAGEMENT OF RECEIVABLES: LITHUANIAN CASE
}

\author{
Rita Remeikiene $^{1}$, Ligita Gaspareniene ${ }^{2}$, Gintare Grigaliune ${ }^{3}$
}

\author{
${ }^{1}$ Mykolas Romeris University, Lithuania, rita.remeikiene@mruni.eu \\ ${ }^{2}$ Mykolas Romeris University, Lithuania, ligitagaspareniene@mruni.eu \\ ${ }^{3}$ Mykolas Romeris University, Lithuania, g.grigaliune@gmail.com
}

\begin{abstract}
Constant changes in business environment determine the significance of receivables to business. The analysis of the current situation in Lithuania has revealed that a substantial part of business enterprises are facing the problem of overdue receivables. This issue emerged as extremely topical after the beginning of the economic crisis in 2008. A number of scientific studies confirmed that the level of receivables has a significant impact not only on smooth business operation but also on operational results and serves as the cause of numerous economic and social problems, faced by both business enterprises and the state. Rising level of receivables determines slower recovery of total economics because it has a negative impact on the sustainability of the public sector of the country. In addition, the scientists highlight economic problems such as production capacity losses, general decrease in competitiveness and failure to satisfy the debt claims. The social problems include the increase in unemployment rate, fall of living standards, dissatisfaction with poor economics of the country and uncertainty about the future. The aim of this article is to analyse the impact of receivables on business in Lithuania. The methods of the research include scientific literature analysis and statistical data analysis.
\end{abstract}

Keywords: receivables; management of receivables; Lithuania.

Type of the paper: Empirical study

JEL Classification: M21.

\section{Introduction}

The effects of economic crisis, which determined the decline of gross domestic product (GDP), rise of unemployment rate and reduction of consumption in both domestic and export markets, can still be felt in current economies. The economic crisis has also had a negative impact on businesses that are still dealing with the problem of high level of receivables. Although it is the case that particular rate of risk is inherent to business, credit risk is one of the types of risk that can have the most detrimental effect on the solvency of business companies (Jasienè, Laurinavičius 2009). Under such circumstances, it is necessary to focus on the analysis, management and control of receivables because the efficiency of debt management has a direct impact on a company's turnover and other critical operational indicators. On the contrary, improper debt management has a negative impact on a company's operational results. Owing to the relatively complicated economic situation, banks are inclined to establish extremely high requirements for credit issuance. Hence, not all business companies are able to comply with the established requirements. For this reason, companies have to control their receivables to escape the shortage of working capital. Receivables as well as the issues of their management have always had a significant impact on business operation results. However, the economic crisis of 2008 determined even faster rise of debt level, which has disclosed the urgency of debt management and the benefits of proper management of receivables on business efficiency.

Both Lithuanian and foreign scientific studies still lack the comprehensive research on the issue of the management of receivables in the private sector. Some scholars (Snieška, Drakšaite 2013; Ribeiro et al. 2012; Sokolov, Sokolova 2012) analysed the issues of public debt and its impact on the economics of the country. Snieška and Drakšaite (2013) studied the sustainability of public debt in small open economies and the impact of the public debt on economic growth. The influence of public debts on 
economic growth of the European States as well as public debt advantages and disadvantages were analysed by Ribeiro et al. (2012). According to Sokolov and Sokolova (2012), who researched the development and determinants of public debt, the issues of public debt have earned rather sufficient scientific attention, although they remain topical in the area of state management. The scientists (Sokolov, Sokolova 2012) noted that global financial crisis of 2008 forced state governments to increase public debt in order to develop private sector and sustain the stable economic situation.

High level of debts is also inherent to private sector. The companies that fail to manage and control their receivables in an appropriate manner, are eventually forced to deal with the problem of insolvent customers. As a result, they lose a significant share of their working capital and delay wage payments, which, in turn, determines lower purchasing power of a country's population and burdens the overall economic growth.

The object of this research is the issues of the management of receivables in Lithuanian business companies. The aim of this article is to analyse the impact of receivables on business in Lithuania. The methods of the research include scientific literature analysis and statistical data analysis.

\section{Literature Review}

According to Malinauskas (2014), risk is inherent to any business, and debt risk refers to the type of risk that has the most significant impact on business efficiency. The issue of receivables has become extremely topical for both domestic and global businesses that operate under conditions of economic crisis. With reference to Kaleininkaite and Trumpaite (2007), management of receivables is one of the most urgent issues for business companies all over the EU. In accordance with Aleknavičienė and Girdžiūtė (2009) and Lamminmaki and Leitch (2011), receivables compose a substantial share of assets in business balance sheets. Lamminmaki and Leitch (2011) noted that nearly 80 percent of transactions are based on sales of goods or services for credit. The analysis of the scientific literature has revealed that a number of scientists - Snieška, Drakšaite (2013), Ribeiro et al. (2012), Sokolov, Sokolova (2012) and others - have researched the issues of public debt and its impact on economics, whereas the issues of debts in private sector have not earned sufficient scientific attention. According to Charitonov (2004), both global and Lithuanian economics are facing the problems of business insolvency. The author proposed that a company's ability to react to ongoing changes as well as business managers' knowledge, perception and comprehension highly determines business success and general existence. This attitude was supported by Norvaišienè and Stankevičienė (2012), with reference to whom, debt level influences not only business activities but also operational results.

Receivables refer to credits, ensured to customers by suppliers. Considering the nature of receivables, they can be treated as a substitute to bank loans (Badu et al. 2012). Hence, the level of receivables is likely to increase during the periods of economic recession when the volumes of issued bank loans decline (Jasienè, Laurinavičius 2009).

The analysis of the scientific literature has enabled to systematise the findings of previous scientific studies on the determinants of receivables (see Table 1).

Table 1. Receivable debt determinants (Source: authors' compilation)

\begin{tabular}{|l|l|}
\hline \multicolumn{1}{|c|}{ Author(s), (year) } & \multicolumn{1}{c|}{ Determinants } \\
\hline Brennan et al. (1988) & $\begin{array}{l}\text { Receivables provide an opportunity of price discrimination. However, supplier's } \\
\text { credit and assurance of discounts for earlier payment allow to employ this measure }\end{array}$ \\
\hline Boissay (2004) & $\begin{array}{l}\text { Receivables determine information asymmetries among companies, suppliers and } \\
\text { banks }\end{array}$ \\
\hline $\begin{array}{l}\text { Lamminmaki, } \\
(2011)\end{array}$ & Leceivables refer to a sales policy measure that allows to attract new customers \\
\hline Snieška, Drakšaité (2013) & Receivables allow to reduce transaction costs in case of frequent purchases \\
\hline Owusu-Manu et al. (2014) & Receivables provide an access to capital for construction contractors globally and \\
\hline
\end{tabular}




\begin{tabular}{|l|l|}
\hline & is an important source of finance in both developed and developing countries \\
\hline Chludek (2011) & $\begin{array}{l}\text { Employment of receivables has some cost saving advantages; receivables offer } \\
\text { flexibility (by offering the possibility to pay invoices flexibly within a certain time } \\
\text { frame, trade credit use improves cash flow synchronisation, in this way reducing } \\
\text { the (opportunity) costs of paying and managing invoices); receivables are generally } \\
\text { automatically granted at purchase by the supplier's general terms and conditions, } \\
\text { so that financing is directly available at purchase, thereby avoiding the transaction } \\
\text { costs associated with the procurement of other funds; receivables serve as implicit } \\
\text { quality insurance because the customer can inspect the quality of delivered goods } \\
\text { or services during the net period, verifying quality before payment. }\end{array}$ \\
\hline Badu et al. (2012) & $\begin{array}{l}\text { Employment of receivables serves as a financial intermediation device whereby } \\
\text { construction vendors act as financial providers to their customers through deferred } \\
\text { payments of goods purchased }\end{array}$ \\
\hline $\begin{array}{l}\text { Norvaišiené, } \\
\text { Stankevičienè (2012) }\end{array}$ & $\begin{array}{l}\text { Receivables promote customers' trust in an enterprise and speak about the ability } \\
\text { of this enterprise to operate flexibly }\end{array}$ \\
\hline Boden, Paul (2014) & $\begin{array}{l}\text { Managed effectively, receivables can confer competitive advantage in terms of } \\
\text { information and signalling, customer relationships and financing of working capital }\end{array}$ \\
\hline Han et al. (2013) & $\begin{array}{l}\text { Receivables (or trade credits), as one off substitution, give another access to SME } \\
\text { finance }\end{array}$ \\
\hline Nobanee, Abraham (2015) & $\begin{array}{l}\text { Receivables are used as a sales policy measure; they allow to adjust sensitivity of } \\
\text { working capital management to the conditions of market imperfection }\end{array}$ \\
\hline
\end{tabular}

Summarising the data presented in Table 1, it can be stated that in some cases, receivables are used with the purpose to increase sales or emerge as a result of information asymmetry or mutual agreement. In accordance with Norvaišienè and Stankevičienè (2012), debtors usually believe that they will be able to pay all their creditors. Mackevičius and Rakšteliene (2005) argued that indebtedness, in fact, causes numerous economic and social problems not only for business companies but also for the state. They distinguished the following economic problems: 1) production capacity losses, 2) general decrease in the competitiveness of country's economics, 3) reduced amounts of taxes collected in the state budget, and 4) failure to satisfy debt claims. Mackevičius and Rakštelienè (2005) also highlighted the following social problems, determined by indebtedness: 1) increase in unemployment rate, 2) fall of the general living standards, 3) population's dissatisfaction with poor economics of the country, and 4) uncertainty about the future.

The authors noted that it is difficult to determine which - economic or social - problems have more significant impact on the development of the state because both of them influence business continuity and population's life standards. According to Kaleininkaite and Trumpaite (2007), lack of experience in debt risk management in dynamic competitive markets determines insufficiently reasoned decisions and negative effects on business.

Thus, receivables must be considered with appropriate accuracy because they not only influence a company's operational efficiency and results but also have the impact on a country's overall economics and population life standards. The majority of scientists agree that debts in private sector affect both business efficiency and economics of the country (see Table 2).

Table 2. The impact of debt ratio increase on business and economy (Source: compiled by the authors with reference to Kuizinaite and Paliulyte (2008), Liu and Rosenberg (2013) and OECD (2012))

\begin{tabular}{|l|l|}
\hline \multicolumn{1}{|c|}{ Author(s), year } & \multicolumn{1}{c|}{ Research results } \\
\hline $\begin{array}{l}\text { Kuizinaitė and Paliulyte } \\
(2008)\end{array}$ & $\begin{array}{l}\text { Constantly increasing debt ratio deepens financial problems, increases risk and } \\
\text { reduces the stability of economy }\end{array}$ \\
\hline Liu, Rosenberg (2013) & $\begin{array}{l}\text { Rising debt ratio slows down economic revival since high level of debts in the } \\
\text { private sector deteriorates sustainability of the public sector }\end{array}$ \\
\hline OECD (2012) & $\begin{array}{l}\text { High debt ratio burdens smooth operation and investment, which makes } \\
\text { country's economy vulnerable. Such findings confirm the results of previous } \\
\text { scientific research on this topic }\end{array}$ \\
\hline
\end{tabular}


Owing to the reasons, explicated in Table 2, debt risk management has become an extremely important issue because each businessperson seeks not only to maintain one's business but also to compete successfully in the dynamic markets, at the same time, promoting revival and stability of economics. Dooley (2000) noted that optimal debt management balances the earnings and expenses, incurred because of customers' failure to fulfil their obligations. According to Grigonytė and Sūdžius (2009), the situation when debt ratio increases stimulates the need to develop a 'mechanism' which would allow to replace the current mode of decision-making. Financial indicators, in particular, liquidity and solvency, are treated as highly informative measures that allow to prognosticate the difficulties in a company's financial state. Such mechanism would enable to escape a part of expenses. This way, the overall solvency ratio would be improved. Hence, business should follow the aim to develop a strategy or a mechanism that would help to manage timely inflows of the revenue (Grigonyte, Sūdžius 2009).

Evidently, development of the model by itself will not eliminate the problem of solvency. Efficient application of the model is no less important. Debt management can be burdened by the fears that application of the model might bring about some negative consequences. Nevertheless, with reference to Aleknavičienė and Girdžiūte (2009), it is possible to defend a company's interests without any negative customers' reactions and with saving the prospects of further co-operation. Employment of psychological measures such as keeping one's word, politeness or originality may highly contribute to this purpose.

The authors of this article agree with the opinion that all market participants are inclined to successful competition. Hence, each customer, even the one who is in debt at the particular moment but can be expected to pay off the debts and continue further co-operation, should be appreciated. Such attitude calls for the development of a system that would allow to recover the debt without losing a potential customer in the future.

Grigonyte (2012) stated that business, by large extent, is influenced by economic cycles. 'Changing economic cycles cause higher than common risks to business. During the periods of changes, the significance of timely revenue highly increases, and receivable debts may determine unwanted negative effects on a company's financial indicators and its reputation' (Grigonyte 2012, p. 1).

The findings of the research, carried out by Jasienè and Laurinavičius (2009), revealed that business companies do not use debt risk reduction measures in the following cases:

1. If trading parties are bound with long-term business relations

2. If managers have personal contacts with a customer

3. If a customer usually pays timely.

However, disregard of debt risk reduction measures might cause extra risk. According to Jasienè and Laurinavičius (2009), more than a half of managers admit having had losses determined by the disregard of debt reduction measures. The fact that a substantial part of business companies are inclined to risk is disclosed by the tendency that only nearly one-third of companies would not sell their products to customers about whom they have acquired any negative information (Jasiene, Laurinavičius 2009). This reveals inclination to assume the largest part of the risks related to sales.

\section{Methodology}

Prevention measures are considered as the most critical factor that determines smooth and qualitative business operation. Debt prevention measures cover the entirety of the measures that could be used to prevent the emergence of debts. Such measures should be used in the early stages of prevention of receivables. They are developed not for the elimination of the debts that have already emerged but for the protection from the emergence of new debts. In order to operate smoothly, it is necessary not only to ensure an appropriate business functioning but also to develop a relevant prevention system that would enable to prevent the chain reaction, meaning that a single debtor can cause bankruptcy of a few 
or more creditors that are interrelated in their business. Hence, implementation of efficient debt prevention measures would determine less common employment of forced debt recovery. Even if the latter measure was invoked, forced debt recovery would become faster and more efficient.

The analysis of the scientific literature (Chludek 2011; Sokolov, Sokolova 2012; Snieška, Drakšaitė 2013; Boden, Paul 2014) proposes that the following steps should be taken by business companies to prevent the emergence of receivable debts: first, business managers or appointed employees should establish a purchaser's or a seller's identity; second, the method of payment, acceptable to both contract parties, should be confirmed; third, all expenses should be estimated, and scenario matrix should be developed; in the fourth step, potential debt should be evaluated, and debt management measures as well as the possible impact of the debt on a company's financial indicators should be anticipated; in the fifth stage, a contract partner, his reputation and significance to a company's business continuity should be assessed; finally, the decision on risk assumption and transaction execution should be made. Only consideration of all of the steps introduced above ensures an appropriate control of the transaction.

With the purpose to research the issues of the management of receivables in Lithuanian business during the period of 2000-2014, the methods of statistical data analysis and interpretation were used in the empirical part of the research. For the evaluation of the current trends of the management of receivables in Lithuanian business during the researched period, the data accumulated from the databases of Lithuanian Department of Statistics and the figures announced by 'Intrum Justitia, Ltd.' in 'European Payment Report 2013, 2014, 2015' were used.

\section{Results}

With reference to Mackevičius (2008), during the period of independence of the country, Lithuanian business companies have passed through numerous events that have had a direct impact on their operation. Particular political events and decisions have determined the current financial state, operational results, stability and development of Lithuanian business companies. Owing to inability to respond to changing economic and political conditions and withstand competitive pressures, a significant number of companies have come through financial difficulties or even bankrupted. Over the period of 1993-2006, bankruptcy was announced for 5,261 Lithuanian companies. Lack of business operation analysis is considered as one of the main causes of bankruptcy. 'Business operation analysis refers to accumulation, comprehensive and objective analysis, and assessment of different economic information on a company's activity, aimed at fulfilment of the defined goals' (Mackevičius 2008, p. 46). 'Under the conditions of market economy, from 2 to 6 percent of business companies bankrupt yearly. Therefore, bankruptcy is treated as a macroeconomic problem, inevitable phenomenon of market economy, or even as an acceptable way of debt recovery' (Mackevičius 2008, p. 26).

With reference to statistics, in 2014, Lithuanian economics revived after the economic crisis of 20082009. Lithuanian GDP increased by 1.3 percent in 2010. Growth of foreign demand, which, to the largest extent, determined the rise of real GDP and also conditioned the improvement of business financial indicators. In 2015, Lithuanian GDP increased by 2.9 percent, which proposes that GDP returned to the pre-crisis level of 2007.

With reference to the data of Lithuanian Department of Statistics (2016), short-term debts to suppliers considerably increased during the analysed period of 2000-2014, in particular over the period of 2008-2009, and reached their peak in 2013, whereas the share of long-term debts was significantly smaller in the amount of total commitments, although it had followed the tendency of increase since the period of 2008-2013. The analysis of the statistical data proposes that debt recovery, which has gained its intensity over the past 14 years, remains one of the most problematic areas in Lithuanian private sector. 


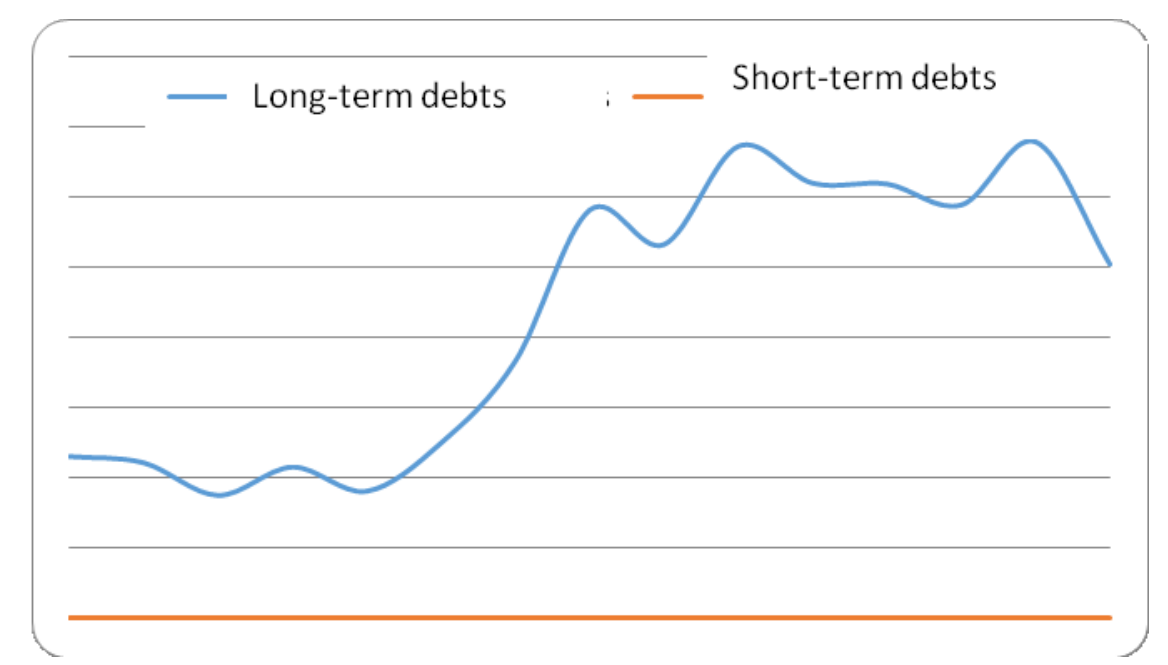

Fig. 1. The rates of long- and short-term debts in Lithuanian private sector over the period of 2000-2014, in thousand EUR (Source: Lithuanian Department of Statistics 2016)

The report, presented by 'Intrum Justitia, Ltd.' (2013), introduced Payment Risk Index for Lithuanian business companies (see Fig. 2). The values of the index should be interpreted as follows:

- the value of 100 stands for no payment risk; payments are made in advance or just after the reception of products or services; no credits are available;

- the value of 101-129 stands for low risk, although relevant observation is required;

- the value of 130-139 stands for the transfer from low to medium-high risk, when risk management and reduction already requires appropriate intervention and actions;

- the value of 140-149 stands for the stage of medium-high risk, when employment of appropriate actions of necessary;

- the value of 150-159 stands for the transfer from medium-high to high risk, when urgent actions must be used for risk reduction;

- the value of 160-169 stands for high risk stage, when urgent actions are vital;

- the value higher than 170 stands for the critical situation with risk management in the company.

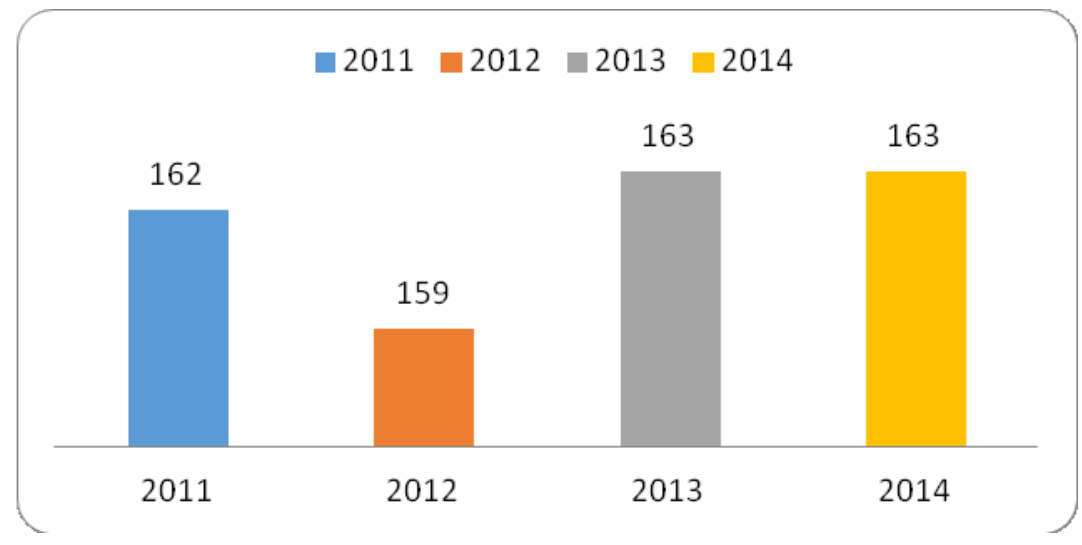

Fig. 2. Payment Risk Index for Lithuanian business companies (Source: compiled by the authors with reference to the data of 'Intrum Justitia, Ltd.', 2013)

Figure 2 reveals that the lowest payment risk was attributed to Lithuanian business companies in 2012, when Payment Risk Index composed 159, although this value of the index stands for the stage of the transfer from medium-high to high risk. In 2010, 2011, 2013 and 2014, Payment Risk Indexes for Lithuanian business companies are attributed to high-risk profile, which shows that the situation calls 
for urgent improvements in the field of debt risk reduction. With reference to the description of the situation, presented by 'Intrum Justitia, Ltd.' (2014), bad debt loss percentage slightly decreased, and payment duration stabilised. However, $57 \%$ of business companies reported no organic growth determined by the recession, and $52 \%$ noted that they were not investing in innovation. Sixty-eight percent of business companies admitted predicting stable late payment risks over the coming 12 months, whilst $16 \%$ declared about anticipation of increased risk.

'Intrum Justitia, Ltd.' (2014) also announced the statistical information on Business-2-Business (B-2B) debt payment delays in Lithuanian business companies (see Fig. 3).

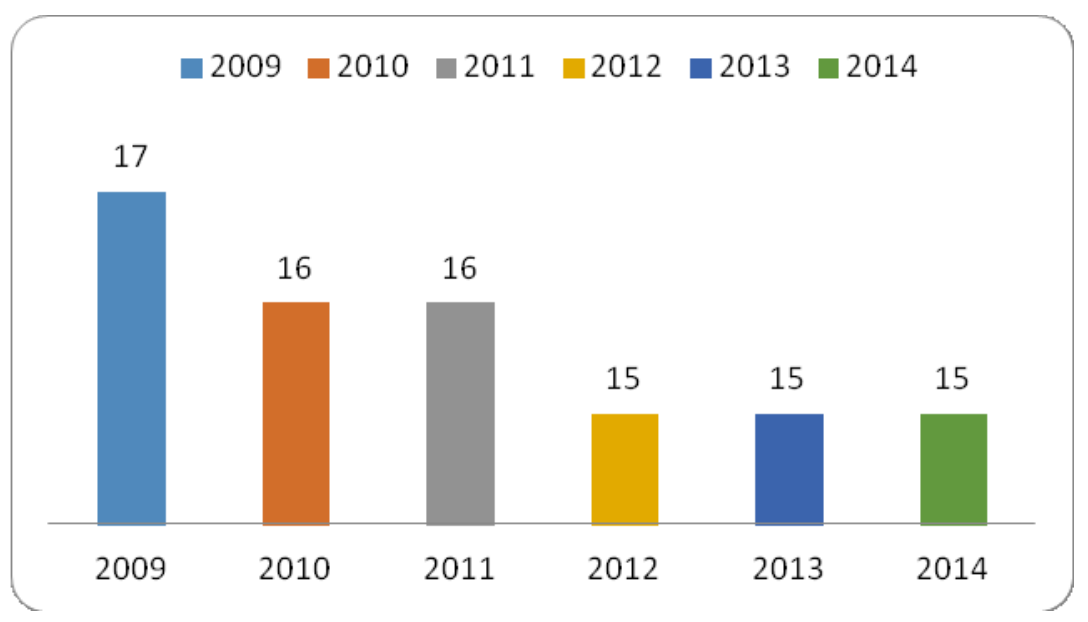

Fig. 3. Average Business-2-Business (B-2-B) debt payment delays in Lithuanian companies, in days (Source: compiled by the authors with reference to the information of 'Intrum Justitia, Ltd.' 2014)

As it can be seen from Figure 3, debt payment delays in Lithuanian companies stabilised over the period of 2012-2014. Nevertheless, the average delay in days is relatively short in comparison with the EU average (47 days in 2014). According to Jasiene and Laurinavičius (2009), debt payment delay terms may vary, depending on the stage of the economic cycle: economic recession determines longer debt payment delays, whereas economic growth makes the delay terms shorter. Hence, better overall economic situation as well as more stable business position should drive debt ratios down. The report of 'Intrum Justitia, Ltd.' (2015) proposes that if payment delays exceed the limit of three or more months, possibilities of debt recovery are extremely small, and such delays are detrimental for the creditors themselves. Thus, all available debt risk reduction measures should be used to recover the debts earlier than the appointed limit.

Summarising, it can be stated that the problems with the management of receivables, faced by Lithuanian business companies in the private sector since the beginning of the economic crisis, have been basically determined by the following reasons:

- considering the value of Payment Risk Index, Lithuanian business companies fall into the category of high risk, when appropriate actions and measures must be used for the management of receivables and commitments;

- the rate of short-term debts to suppliers decreased by 9.75 percent from 2013 to 2014;

- the average debt payment delay is equal to 15 days, and this tendency has not changed over the past three years.

Considering the impact of the level of receivables on business and the overall economics of the country, it should be noted that in order to operate efficiently, Lithuanian business managers must constantly analyse the financial state of their companies, business partners, and current and potential customers. Such analysis would enable to reduce the level of receivables, would increase the possibility to receive timely payments for provided products and services, would guarantee the 
sufficiency of working capital and would help to escape the delays in wage payments. As a result, business efficiency would vastly increase, which, in turn, would contribute to the upswing of the overall economics of the country.

\section{Conclusions}

The analysis of the scientific literature has revealed that in some cases, receivables are used with the purpose to increase sales or emerge as a result of information asymmetry or mutual agreement. Financial indicators, in particular liquidity and solvency, are treated as highly informative measures that allow prognosticating the difficulties in a company's financial state. Development of a mechanism would allow replacing the current mode of decision-making, would enable to escape a part of expenses and would contribute to the improvement of the overall solvency ratio. Hence, business companies should follow the aim to develop a strategy or a mechanism to manage timely inflows of their revenue. For the appropriate control of transactions and management of receivables, business companies should take the following steps: first, a purchaser or seller's identify should be established; second, the method of payment, acceptable to both contract parties, should be confirmed; third, all expenses should be estimated, and scenario matrix should be developed; fourth, potential debt should be evaluated, and debt management measures as well as possible impact of the debt on a company's financial indicators should be anticipated; in the fifth stage, a contract partner, his reputation and significance to a company's business continuity should be assessed; finally, the decision on risk assumption and transaction execution should be made.

The empirical research has revealed that considering the value Payment Risk Index, Lithuanian business companies fall into the category of high risk, where appropriate actions and measures must be used for the management receivables and commitments; the rate of short-term debts to suppliers in the private sector decreased by 9.75 percent from 2013 to 2014; the average debt payment delay is equal to 15 days, and this tendency has not changed over the past three years. The findings, based on the analysis of the statistical data, proposed that Lithuanian business companies do not manage their receivables with appropriate efficiency and are attributable to a high-risk profile. Hence, the current situation calls for urgent improvements in the field of debt risk reduction.

\section{References}

Aleknavičienè, V., \& Girdžiūtė, L. (2009). Tarptautinių atsiskaitymų kredito rizikos valdymas mažose ịmonėse. Vadybos mokslas ir studijos - kaimo verslu ir ju infrastruktūros plètrai, 18(3), 5-12.

Badu, E., Edwards, D. J., \& Owusu-Manu, D. G. (2012). Trade credit and supply chain delivery in the Ghanaian construction industry: Analysis of vendor interactions with small to medium enterprises. Journal of Engineering, Design and Technology, 10(3), 360-379.

Boden, R., \& Paul, S. Y. (2014). Creditable behaviour? The intra-firm management of trade credit. Qualitative Research in Accounting \& Management, 11(3), 260-275.

Boissay, F. (2004). Crédits interentreprises et délais de paiement : une théorie financière. Annales d'Economie et de Statistique, (73), 101-118.

Brennan, M. J., Maksimovic, V., \& Zechner, J. (1988). Vendor Financing. Journal of Finance, 43(5), 11271141.

Charitonov, V. (2004). Imonių bankroto prevencija. Metodologinis aspektas. Organizaciju vadyba: sisteminiai tyrimai, (30), 67-80.

Chludek, A. K. (2011). A note on the price of trade credit. Managerial Finance, 37(6), 565-574.

Dooley, M. P. (2000). Debt management and crisis in developing countries. Journal of Development Economics, (63), 45-58.

Grigonytė, I. (2012). Uždelstų debitorinių įsiskolinimų įmonèms įvertinimas Lietuvos rinkoje. Business in XXI Century, (2), 1-8. 
Grigonytė, I., \& Sūdžius, V. (2009). Mokèjimų rizikos įvertinimas Lietuvos, Latvijos ir Estijos rinkose. Verslas, vadyba ir studijos, (4), 7-20.

Han, X., Wang, X., \& Wang, H. (2013). The inter-enterprise relationship and trade credit. Nankai Business Review International, 4(1), 49-65.

Intrum Justitia OY (2013). European payment index 2013. Accessed [11.01.2016]. Available from Internet: http://intrumjustitia-mpr.creo.tv/130513/eur_350_billion_in_bad_debt_written_off_by_european_businesses

Intrum Justitia OY (2014). European payment index 2014. Accessed [11.01.2016]. Available from Internet: http://intrum.crmplatform.nl/documents/IJ_EPI-2014_ENG_Sec.pdf

Intrum Justitia OY (2015). European payment report 2015. Accessed [11.01.2016]. Available from Internet: https://www.intrum.com/Press-and-publications/European-Payment-Report/EPR2015/

Jasienè, M., \& Laurinavičius, A. (2009). Kredito rizikos valdymo įmonèse problemos ir jų sprendimo būdai. Verslas: teorija ir praktika, (6), 15-29.

Kaleininkaitè, L., \& Trumpaitè, I. (2007). Verslo rizikos valdymas ir jo tobulinimas. Verslas: teorija ir praktika, 8(3), 176-181.

Kuizinaitè, V., \& Paliulytė, I. (2008). Kapitalo struktūros įtakos įmonių veiklos finansiniams rodikliams analizè. Jaunuju mokslininku darbai, 1(17), 138-149.

Lamminmaki, D., \& Leitch, P. (2011). Refining Measures to Improve Performance Measurement of the Accounts Receivable Collection Function. JAMAR, 9(2), 1-20.

Lithuanian Department of Statistics (2016). Statistiniu rodikliu analizė. Accessed [15.01.2016]. Available from Internet: http://osp.stat.gov.lt/

Liu, Y., \& Rosenberg, C. B. (2013). Legal and European Department; Dealing with private debt distress in the wake of the European financial crisis. IMF working paper 1344. Accessed [10.01.2016]. Available from Internet: https://www.imf.org/external/pubs/ft/wp/2013/wp1344.pdf

Mackevičius, J. (2008). Imonių veiklos analize - informacijos rinkimo, tyrimo ir vertinimo Sistema. Informacijos mokslai, (4), 46-56.

Mackevičius, J., \& Rakštelienè, A. (2005). Altman modelių taikymas Lietuvos įmonių bankrotui prognozuoti. Ekonomikos ir teorijos praktika: Pinigu studijos, (1), 24-42.

Malinauskas, G. (2014). Pirkèjų skolų valdymo modelis smulkaus verslo įmonèje. Jaunasis mokslininkas, (4), 40-48.

Nobanee, H., \& Abraham, J. (2015). Current assets management of small enterprises. Journal of Economic Studies, 42(4), 549-560.

Norvaišienè, R., \& Stankevičienè, J. (2012). The relationship of corporate governance decision on capital structure and company's performance: evidence from Lithuanian food and beverages industry companies. Economics and management, 17(2), 480-486.

OECD (2012). Debt \& Macroeconomic stability. OECD Economics Department Policy Notes, (16), 1-36.

Owusu-Manu, D. G., Holt, G. D., Edwards, D. J., \& Badu, E. (2014). Determinants of trade credit supply among the Ghanaian construction sector. Built Environment Project and Asset Management, 4(4), 368-383.

Ribeiro, H. N. R., Vaicekauskas, T., \& Lakštutienè, A. (2012). The effect of public debt and other determination the economic growth of selected European countries. Economic and management, 17(3), 914-921.

Snieška, V., \& Drakšaitè, A. (2013). Evaluation of sustainability of the general government debt in a small open economy. Mediterranean journal of social sciences, 4(9), 610-618.

Sokolov, B., \& Sokolova, Y. (2012). The history of government debt justification. Economic and management, 17(3), 922-928. 